\title{
Effect of jackfruit seed fortification on high calcium milk on bone collagen density
}

\author{
Aulia Ayub*, Fun Nagede Adinsyah*, Arum Trisnaningtyas Sugiyanto Putri*, Presty Dwi Fitriani ${ }^{*}$ Risma Martasuri**, \\ Tetiana Haniastuti*** \\ *Dentist Study Program, Faculty of Dentistry, Universitas Gadjah Mada, Yogyakarta, Indonesia \\ **Pharmacy, Faculty of Pharmacy, Universitas Gadjah Mada, Yogyakarta, Indonesia \\ ***Department of Oral Biology, Faculty of Dentistry, Universitas Gadjah Mada, Yogyakarta, Indonesia \\ JI Denta No. 1 Sekip Utara, Yogyakarta, Indonesia; e-mail: aulia_ayub@ugm.ac.id
}

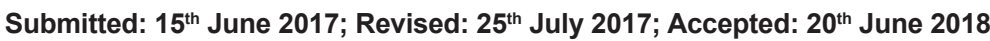

\begin{abstract}
Osteoporosis is a bone disease characterized by reduced bone mass and damage to the microarchitecture of bone tissue. One of osteoporosis types is primary type-1 osteoporosis or postmenopausal osteoporosis due to estrogen deficiency. Calcium is an important mineral that plays a central role in the formation of bone strength structure. Jackfruit seeds (Artocarpus heterophyllus) contain isoflavones that can replace the role of estrogen in the body. Fortification of jackfruit seeds and high calcium milk can be a potential alternative for the treatment of postmenopausal osteoporosis. The purpose of this study was to determine the effect of drinking high calcium milk fortified with jackfruit seed extract (Artocarpus heterophyllus) on alveolar bone collagen fiber density of menopause induced rats. Twenty-five Sprague dawley rats were included in this study. Twenty Sprague dawley rats were ovariectomized, while 5 rats were left untreated (normal control group). Seven days after ovariectomy was performed, 5 rats were treated with fortification of jackfruit seed extract and high calcium milk, 5 rats were treated with jackfruit seed extract, 5 rats were treated with high calcium milk, and 5 rats were left untreated (ovariectomized control group). The treatments were done for 28 days. The rats were euthanized and the alveolar bone was taken and processed for a histological specimen. Alveolar bone collagen fibers were observed under a binocular microscope with 100 magnification. Kruskal-Wallis result showed there was a significant difference in the alveolar bone collagen fiber density among these groups $(p<0.05)$. Mann-Whitney $U$ Test showed a significant difference $(p<0.05)$ in the alveolar bone collagen fiber density of the rats treated with fortification of jackfruit seed extract and high calcium milk compared to the group treated with jackfruit seed extract, that with high calcium milk, or ovariectomized control group. No significant difference in alveolar bone collagen fiber density was found between the group treated with fortification of jackfruit seed extract and high calcium milk and the normal control group $(p>0.05)$. In conclusion, consuming high calcium milk fortified with jackfruit seed extract increases the density of alveolar bone collagen fibers.
\end{abstract}

Keywords: bone collagen; fortification; jackfruit seed extract; menopause; osteoporosis

\section{INTRODUCTION}

Osteoporosis is one of the major health problems for people in the world, particulary in developing country. ${ }^{1}$ In Indonesia, the number of elderly woman with menopause always increases from year to year. More than $30 \%$ woman suffer from osteoporosis at the age of 60-70 years old and the incidence increases to $70 \%$ at the age of 80 and above.

Osteoporosis is a bone disease marked by the loss of bone mass and damage to bone tissue microarchitecture. ${ }^{2}$ That condition will increase bone fragility and risk of fracture. A decrease in the bone mass of a person with osteoporosis occurs because of the body's inability to manage mineral content in the bone as a result of interference in bone metabolism process. ${ }^{1}$

Primary osteoporosis type I or usually known as postmenopausal osteoporosis is a type of osteoporosis caused by post-menopausal estrogen deficiency. This condition causes regulation enhancement of some cytokines that work to absorb 
bone like Interleukin-1 (IL-1) and Interleukin-6 (IL-6). Esterogen deficiency in menopausal woman causes bone turnover process to become unbalanced. This condition causes bone resorption process to exceed bone formation process. ${ }^{3}$

Alveolar bone is one of the bones affected by an imbalance betwen bone resorption and deposition in people with osteoporosis. The occurence of osteoporosis in alveolar bone is affected by systemic factors like a decrease in estrogen hormone production in post-menopausal woman and local factors like periodontal diseases which can worsen the occurence of alveolar bone loss. ${ }^{4}$ Osteoporosis detection method through alveolar bone especially the mandible is now increasingly developed because of its wide availability and cheaper inspection fees. ${ }^{5}$

Bone is a hard tissue made by bone mineral component and bone matrix with a ratio of $2: 1$. The main component of bone is calcium, meanwhile the main component of bone matrix is collagen. Type I collagen is the largest component that forms matrix. ${ }^{6}$ Type 1 collagen respresents about $90 \%$ of the total protein matrix formed by fibrils with a diameter of about $80-100 \mathrm{~nm}$ and a length of about $10 \mu \mathrm{m}^{7}$

Bone formation can be disturbed by synthesis decrease and type 1 matrix collagen secretion and enhancement of protease specific activity like cathepsin $\mathrm{K}$ or collagenase which can digest collagen matrix. Bone mineralization is affected by the formation of a dense collagen which will become a place to settle calcium. The process is a dynamic process in bone formation cycle so that if bone disease like osteoporosis occurs, bone mineral density will decrease. ${ }^{8}$ Osteoporosis will cause the loss of calcium and collagen in bones. ${ }^{6}$

The general management for people with menopause is to increase calcium, vitamin $D$, and milk consumption. However, giving a high-calcum milk to woman with menopause conditions is still considered ineffective. A nutritional survey shows that a high prevalence of osteoporosis occurs in $30-40 \%$ of women in menopause age who regularly consume milk in Indonesia. ${ }^{9}$
Jackfruit whose latin name is Artocarpus heterophyllus is one type of plant that belongs to Moraceae family. Jackfruit seed forms about $10-15 \%$ of the fruit mass. ${ }^{10}$ These seeds contain lignan, isoflavone, saponin, and other nutrients like fiber, vitamin, mineral, calcium, and phospor which have the benefit as anticancer, antihypertension, antiaging, antioxidant, antiulcer, and many more. ${ }^{11}$

Isoflavone belongs to flavonoid group which is classified as phytoesterogen because the ability of its molecules is similar to that of estrogen molecules. Isoflavone can be used as hormone replacement in menopausal woman. Other than jackfuit seeds, previous studies mentioned that isoflavone with functional structure similar to estrogen (17-beta-estradiol) is known to affect the works of osteoblasts and osteoclasts which can be observed through the indicators of bone mineral density, marker of bone turnover rate, and bone mechanical strength in menopausal woman. Isoflavones work by binding to estrogen receptors on the surface of the target cell. ${ }^{12}$

Based on this explanation, research was needed to examine the effect of drinking high calcium milk mixed/fortified with jackfruit extract (Artocarpus heterophyllus) on alveolar bone collagen density of menopause induced mice. The purpose of this study was to determine the effect of drinking high calcium milk fortified with jackfruit seed extract on alveolar bone collagen density of menopause induced mice.

\section{MATERIALS AND METHODS}

This research method has been approved by the Health Research Ethics Unit of Faculty of Dentistry Universitas Gadjah Mada. Jackfruit seeds were collected from one of the jackfruit sellers in Kotabaru, Yogyakarta. Identification of jacktruit seed species was carried out at the Laboratory of Plant Systematics, Faculty of Biology UGM, and the result showed that the species of the jackfruit seed was Artocarpus heterophyllus. Jackfruit seed extraction was carried out by maceration using $70 \%$ ethanol. Jackfruit seeds were cut into small pieces and baked at $105{ }^{\circ} \mathrm{C}$ for $2-3$ days to remove the water content. The jackfruit seed powder from the 

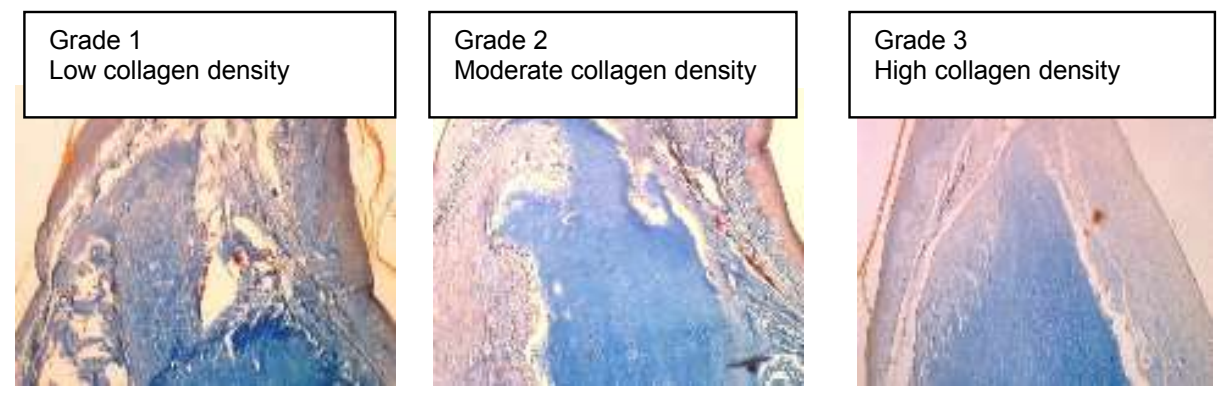

Figure 1. Interpretation of scoring of collagen fiber density (based on the study data). A : Grade 1, low collagen density. B : Grade 2, Medium collagen density. Grade 3 : High collagen density.

milling was then mixed with $70 \%$ ethanol with a ratio of $1: 10(1 \mathrm{~kg}$ of jackfruit seed extract powder in 10 liters of ethanol), stirred for 30 minutes and leave it for 24 hours. The stirring results were filtered 3 times to separate the filtrate and the pulp. The filtrate was sprayed at a temperature of $80^{\circ} \mathrm{C}$ by adding $1: 1$ maltodextran, resulting in jackruit seed extract powder.

Before the spray drying was carried out, $10 \mathrm{~mL}$ of jackfruit seed extract filtrate was tested for Thin Layer Chromatography (TLC) that was evaporated by heating, so that some ethanol solution evaporated and a thicker filtrate was obtained. The TLC test was used to determine the flavonoid phytoetrogen content in jacfruit seed extract. TLC test used the stationary phase in the form of Silica Gel 60 F254 and the mobile phase in the form of hexane : ethyl acetate : formic acid with a ratio of $6: 4: 0.2$, with a comparison of $10 \mathrm{mg} / 1 \mathrm{ml}$ Quercetin ethanol with sitoborat detection. After Ultra Violet beamed with a wavelength of 336 it was found that the results were yellow, indicating that the preparation of jackfruit seed extract that we used positively contained flavonoid phytoestrogen.

Twenty-five female mice aged 50-60 days, weighing \pm 100 grams were used in this study. Twenty from these twenty-five mice were ovariectomized (OVX) to induce menopause. Before the ovariectomy process, the twenty mice were anesthetized using $10 \%$ ketamine at a dose of $50 \mathrm{mg} / \mathrm{kg}$ and xylazine $2 \%$ with a dose of $5 \mathrm{mg} / \mathrm{kg}$ BW intramuscularly. Ovarioectomy was done by ligating and removing the mouse ovary to obtain artificial menopausal conditions. After ovariectomy, the mice were rested for healing for seven days. Twenty-five mice were divided into five test group with each group consisting of five mice, unovarioectomized mice and not treated as group I, ovarioectomized mice and not treated as group II, then overioectomized mice given fortification of jacfruit seed extract and high calcium milk as group III, ovarioectomized mice then given jackfruit seed extract as group IV, and ovarioectomized mice then given high calcium milk as group $\mathrm{V}$. Oral treatment was given once a day for tewnty-eight days with a dose of $5.4 \mathrm{mg} / \mathrm{kg}$ BW (Body weight) for ingredients in the form of jackfruit seed extract powder, high calcium milk, and fortification of jackfruit seed extract with high calcium milk.

Measurement of alveolar bone collagen density was calculated by scoring in 5 visual fields of each preparation and averanged by using an objective lens with $100 x$ magnification with the help of Optilab® software. Collagen fiber will appear in the form of a combination of fine blue fibers called fibrils. Bone collagen density scoring is performed with the following interpretation : grade 1 show low alveolar bone collagen density, grade 2 indicates moderat alveolar bone density, and grade 3 shows high alveolar bone collagen density.

The observation data on collagen fiber density were obtained from two observers in the form of ordinal qualitative data. The data were then analyzed using nonparametric analysis with Kruskal Wallis test and Posthoc test with Mann Whitney $U$ Test to determine the significance of the mean differences among the groups. 


\section{RESULTS}

Table 1. The median value of collagen fiber density in each group

\begin{tabular}{lcc}
\hline Group & N & Median \\
\hline Group I & 5 & 3 \\
Group II & 5 & 1 \\
Group III & 5 & 3 \\
Group IV & 5 & 2 \\
Group V & 5 & 2 \\
\hline
\end{tabular}

where:

Group I : normal mice without ovarioectomy

Group II : post ovarioectomy

Group III : post ovarioectomy given jackfruit seed extract and high calcium milk

Group IV : post ovarioectomy given jackfruit seed extract

Group V : post ovarioectomy given high calcium milk

Table 2. Kruskal-Wallis test results of alveolar bone collagen fiber density

\begin{tabular}{lcc}
\hline \multicolumn{1}{c}{ Group } & Mean Rank. & $\mathrm{p}$ \\
\hline Group I & 96.46 & \\
Group II & 19.96 & \\
Group III & 91.59 & $0.000^{*}$ \\
Group IV & 70.32 & \\
Group V & 36.76 & \\
\hline
\end{tabular}

where :

Group I : normal mice without ovarioectomy

Group II : post ovarioectomy

Group III : post ovarioectomy given jackfruit seed extract and high calcium milk

Group IV : post ovarioectomy given jackfruit seed extract

Group V : post ovarioectomy given high calcium milk

*: the difference in collagen fiber density was significant, $p$ $<0.005$

Table 3. Comparative results of Mann Whitney $U$ Test for alveolar bone collagen fiber density

\begin{tabular}{ccccc}
\hline & $\begin{array}{c}\text { Kelompok } \\
\text { I }\end{array}$ & $\begin{array}{c}\text { Kelompok } \\
\text { II }\end{array}$ & $\begin{array}{c}\text { Kelompok } \\
\text { III }\end{array}$ & $\begin{array}{c}\text { Kelompok } \\
\text { IV }\end{array}$ \\
\hline $\begin{array}{c}\text { Kelompok } \\
\text { I }\end{array}$ & & & & \\
\hline $\begin{array}{c}\text { Kelompok } \\
\text { II }\end{array}$ & $0,000^{*}$ & & \\
\hline $\begin{array}{c}\text { Kelompok } \\
\text { III }\end{array}$ & 0,324 & $0,000^{*}$ & & \\
\hline $\begin{array}{c}\text { Kelompok } \\
\text { IV }\end{array}$ & $0,000^{*}$ & $0,000^{*}$ & $0,002^{*}$ & \\
\hline $\begin{array}{c}\text { Kelompok } \\
\text { V }\end{array}$ & $0,000^{*}$ & $0,000^{*}$ & $0,000^{*}$ & $0,000^{*}$ \\
\hline
\end{tabular}

where :

Group I : normal mice without ovarioectomy

Group II : post ovarioectomy

Group III : post ovarioectomy given jackfruit seed extract and high calcium milk

Group IV : post ovarioectomy given jackfruit seed extract

Group V : post ovarioectomy given high calcium milk

*: the difference in collagen fiber density was significant, $p$ $<0.005$
Table 1 shows that the post ovarioectomy group given jackfruit seed extract and high calcium milk and the normal mice group had the same median value and this value was the highest median value compared to the other three groups. This shows that fortification of jackfruit seed extract and high calcium milk has an effect on collagen fiber density, and the results that are not much different from the normal control group without ovarioectomy. Posthoc test using Mann Whitney $U$ Test was conducted to determine the mean differences in bone collagen fiber density between groups.

Mann Whitney test result (Table 3) shows differences in bone collagen density in the normal mice group compared to the post ovarioectomy group with a significance of $p=0.000$. This shows that ovarioectomy can significantly reduce collagen fiber density. The collagen density among four groups, i.e. the post ovarioectomy group, the post ovarioectomy group given fortified jackfruit seed extract and high calcium milk, the post ovarioectomy group given jackfruit seed extract, and the post ovarioectomy group given high calcium milk, had a significance of $p<0.05$. This means that the fortification of jackfruit seed extract and high calcium milk, jackfruit seed extract, and high calcium milk can significantly increase bone collagen fiber density.

\section{DISCUSSION}

The results showed that there was a decrease in the density of bone collagen fibers in the group of post overioectomy mice. Histologically, the appereance of alveolar bone collagen fibers was irregular dan less dense compared to that in normal mice. These results prove that osteoporosis induction performed in mice through ovarioectomy was successful because the density of bone collagen fibers dropped significantly. ${ }^{13}$ Previous research suggests that primary type 1 osteoporosis or postmenopausal osteoporosis occurs as a result of the removal of ovary or what is commonly called artificial menopause. The removal of ovary in tested animal causes a deficiency of estrogen production. The state of estrogen production deficiency in menopause condition causes a decrease in 
Majalah Kedokteran Gigi Indonesia. August 2018; 4(2): 82 - 88 ISSN 2460-0164 (print)

ISSN 2442-2576 (online)

osteoprotegerin (OPG) production by osteoblasts which serves to inhibit the occurence of bonding between RANKL and RANK. Inadequate OPG production is not able to inhibit the bonding between the RANK and RANKL, so such bonding will still occur. The occurrence of a bonding between RANK and RANKL followed by active c-Fms receptors in osteoclast progenitor cells by Macrophage Colony Stimulating Factor (M-CSF) will lead to proliferation and increased survival of osteoclast progenitors, and cause differentiation of osteoclast progenitors. ${ }^{14}$ The differentiation of osteoclast progenitors will produce mature osteoclasts that will eventually be activated to perform bone resorption. Osteoclasts that have been active will attach to the surface of the bone and release $\mathrm{H}^{+}$ions, causing the condition to become more acidic. The acidic condition causes dissolution of bone hydroxyapatite crystals which is then followed by the removal of cathepsin $K$ enzyme or collagenase. $T$ enzyme is reponsible for digesting the bone collagen matrix, so that the condition of estrogen deficiency is observed to decrease the density of bone collagen fibers. ${ }^{15}$

Based on the results of the study, the administration of high calcium milk can increase the bone collagen fiber density in post ovarioectomy mice. The calcium content in milk is a therapeutic alternative for patients with postmenopausal osteoporosis because calcium plays a role in the bone remodeling process and inhibits bone resorption. Calcium plays an important role in achieving peak bone mass and preventing bone loss. ${ }^{16}$ The availability of abundant extracellular calcium causes an increase in intracellular calcium by calcium-sensing reseptop (CaSR) mediated by PLC activation which will cause an increase in IP3, then calcium activates calmodulin (CaM) which activates CaMKII and calcineurin of AP-1 which will play a role in regulating the poliferation, chemotaxis, and defferentiation of osteoblasts. When $\mathrm{Ca}^{2+}$ ions increase, $\mathrm{Ca}^{2+} / \mathrm{CaM}$ is activated. The sigma will induce osteoblast proliferation through CaMKII activation and c-fos expression thereby inhibiting osteoblast differentiation through $\mathrm{Cn}$ stimulator and reduction of fra-2 expression. ${ }^{17}$ When $\mathrm{Ca}^{2+}$ ions decrese, activation of calmodulin decreases due to reduced activity of CaMKII and $\mathrm{Cn}$. This causes reduced osteoblast proliferation due to reduced c-fos expression and stimulates osteoblast differentiation due to increased expression of fra-2. Increased osteoblast activity has an effect on increasing the secretion of bone collagen fibers on the extracellular matrix, so that in this study alveolar bone collagen fibers in the group given high calcium milk were observed to be thicker than those in the post ovarioectomy group.

The results showed that the administration of jackfruit seed extract can increase the bone collagen fiber density in post ovarioectomy mice. This occurs because the content of isoflavones in jackfruit seed extract with estrogen-like molecules can replace the role of estrogen in the body through its association with estrogen receptors in osteoblast cells. The bonding between isoflavones that have diffused into cells with estrogen receptors in the cytoplasm will penetrate into the nucleus (translocation). Inside the nucleus, the bonding between isoflavones and estrogen receptors will bind to certain parts of DNA. The process initiates the occurrence of complex genetic transcription, causing an anabolic activation of osteoblast cells. As a result of the complex genetic transcription, the production of Transforming Growth Factor- $\beta$ (TGF- $\beta$ ) and Insuline Like Growth Factor-1 (IGF-1) increases. Increased production of TGF- $\beta$ and IGF-1 induces the proliferation and differentiation of osteoblasts, so that the number of osteoblasts increase. ${ }^{18}$ In addition to isoflavones, jackfruit seeds also contain calcium. ${ }^{19}$ The calcium content in jackfruit seed through the mechanism of extracellular calcium will support isoflavones in increasing the proliferation and differentiation of osteoblasts. Osteoblasts are cells that are responsible for secreting bone extracellular matrix or osteoids which are mostly composed of type 1 collagen so that if there is an increase in the number of osteoblasts it will be followed by an increase in type 1 collagen. ${ }^{14}$ Increased type 1 collagen the bone secretion in the group given jackfruit seed extract, causing the bone collagen fibers to appear denser than that in the post ovarioectomy group. 
Based on the results of the study, giving fortification of jackfruit seed extract and high calcium milk can increase the density of collagen fibers in post ovarioectomy mice. These result indicate that mixing or fortification of jackfruit seed extract and high calcium milk which contains isoflavones and calcium in it can increase the density of alveolar collagen fibers through two mechanisms, which is through isoflavone bonding with estrogen receptors and through the mechanism of increasing extracellular calcium as previously mentioned. Both mechanisms will increase the proliferation, differentiation and chemotaxis of osteoblasts, so that osteoblast activity increases. Increased activity of osteoblasts will cause increased osteoid secretion by osteoblasts. Osteoid is mostly composed of type 1 collagen, so that if osteoid secretion increases, type 1 collagen secretion will increase. ${ }^{20}$

The results showed that the collagen fiber density of the post ovarioectomy group which was given the fortification of jackfruit seed extract and high calcium milk was not significantly different from that of the normal mice group. These result indicate that the fortification of jackfruit seed extract and high calcium milk can restore bone collagen fiber density similar to that in normal mice conditions. These results are supported by a research conducted by Zheng et al who suggested that administration of isoflavones and calcium in patients with postmenopausal osteoporosis is an effective treatment. Increased density of bone collagen fibers was observed in the study. ${ }^{21}$

Based on the results of the study, the post ovarioectomy group which was given jackfruit seed extract had a higher collagen fiber density compared to the post ovarioectomy group given high calcium milk. This can occur because in the condition of postmenopausal osteoporosis, the body lacks estrogen hormone which is one of the important hormones that play a role in regulating bone formation. ${ }^{14}$ However, in these circumstances the body does not necessarily lack of extracellular calcium. Jackfruit seed extract with isoflavone content can be an answer to the need for estrogen hormone in postmenopausal osteoporosis conditions. The body in postmenopausal osteoporosis conditions tends to require a compound that can restore the balance of estrogen in the body so that its role in regulating bone formation can continue to run according to the normal physiology. ${ }^{22}$ That is what is likely to cause isoflavones in jackfruit seed extract to be more effective in increasing bone collagen density than calcium in high calcium milk. This result is consistent with a research conducted by Greendale et al. in 2002, showing that the replacement of estrogen in postmenopausal osteoporosis conditions is more effective in increasing bone mass than taking calcium supplements. ${ }^{22}$

\section{CONCLUSION}

The groups given fortification of jackfruit seed extract and high calcium milk, that of jackfruit seed extract, and that of high calcium milk can increase the collagen fiber density of alveolar bone in meopausal mice, with the most significant increase in collagen fiber density shown after oral administration in the group given fortified jackfruit seed extract and high calcium milk.

\section{ACKNOWLEDGEMENT}

Our thanks goes to Dikti for the 2017 Student Creativity Program grant given to us for this research. Mr. Wasino as a LPPT technician who helped with ovarioectomy and management of test animals.

\section{REFERENCES}

1. Kemenkes RI. Data dan kondisi penyakit osteoporosis di Indonesia. Jakarta: Pusat Data dan Informasi Kementerian Kesehatan Republik Indonesia; 2015.

2. Kapetanovic A, Avdic D. Dietary calcium intake and osteoporosis in postmenopausal women living in sarajevo area. Journal of Health Sciences. 2012; 2(2): 118-121.

3. Arjmandi BH, Smith BJ. Soy isoflavones osteoprotective role in postmenopausal women: mechanism of action. J Nutr Biochem. 2002; 13(3): 130-137.

4. Hildebolt CF. Osteoporosis and oral bone loss. Dentomaxillofacial Radiology. 1997; 26(1): 3-15. 
Majalah Kedokteran Gigi Indonesia. August 2018; 4(2): 82 - 88 ISSN 2460-0164 (print)

ISSN 2442-2576 (online)

5. Lestari S, Widyaningrum R. Hubungan fraksi area trabekula anterior mandibula dengan kepadatan tulang lumbar spine untuk deteksi dini osteoporosis. Majalah Kedokteran Gigi Indonesia. 2017; 3(1): 43-50.

6. Kurt-Sirin O, Yilmaz-Aydogan $\mathrm{H}$, Uyar $M$, Seyhan MF, Isbir T, Can A. Combined effects of collagen type I Alpha1 (COL1A1) Sp1 polymorphism and osteoporosis risk factors on bone mineral density in Turkish Postmenopausal Women, Gene. Elsevier B.V. 2014; 540(2): 226-231.

7. Sroga GE, Vashishth D. Effect of bone matrix protein on fracture and fragility in osteoporosis. Curr Osteoporos Rep. 2012; 10(2): 141-150.

8. Rodriguez JP, Montecinos L, Rios S, Reyes P, Martínez J. Mesenchymal stem cells from osteoporotic patients produce a type i collagen-deficient extracellular matrix favoring adipogenic differentiation. Journal of Cellular Biochemistry. 2000; 79(4): 557-565.

9. Feskanich D, Willett WC, Colditz GA. Calcium, vitamin $\mathrm{D}$, milk consumption, and hip fractures: a prospective study among postmenopausal women. The American Journal of Clinical Nutrition. 2003; 77(2): 504-511.

10. Maurya P, Mogra R. Assessment of consumption practices of jackfruit (Artocarpus heterophyllus lam.) Seeds in Villages of Jalalpur Block District Ambedarnagar (U.P.) India. Remarking. 2016; 2(8): 73-75.

11. Nandkule VD, Masih D, Sonkar C, Patil DD. Development and quality evaluation of jackfruit seed and soy flour noodles. International Journal of Sciences, Engineering, and Technology. 2015; 3(3): 802-806.

12. Al-Anazi FA, Qureshi VF, Javaid K, Qureshi S. Preventive effects of phytoestrogens against postmenopausal osteoporosis as compared to the available therapeutic choices: an overview. J Nat Sci Biol Med. 2011; 2(2): 154-163.
13. Ghani L. Seluk beluk menopause. Media Penelit Pengemb Kesehat. 2009; 19(4): 193-197.

14. Lerner UH. Bone remodeling in post-menopausal osteoporosis. J Dent Res. 2006; 85(7): 584-595.

15. Jee SS. Development of collagen-hydroxyapatite nanostructured composites via a calcium phosphate precursor mechanism. USA: ProQuest; 2009.

16. Muliani. Pemberian kalsium laktas peroral dan berenang menurunkan osteoklas dan meningkatkan osteoblas pada tulang radius mencit (mus musculus) perimenopausal. J IIm Kedokt. 2012; 43(3): 169-178.

17. Zayzafoon M. Calcium/Calmodulin signaling controls osteoblast growth and differentiation. J Cell Biochem. 2006; 97(1): 56-70.

18. Djuwita I, Pratiwi IA, Winarto A, Sabri M. The proliferation and differentitaion rate of rat bone cells in in vitro culture medium containing cissus quadragula salisb extract. J Kedokt Hewan Indonesia. 2012; 6(2): 75-80.

19. Puspaningtyas DE. The miracle of fruit. Salemba. Jakarta; 2013.

20. Kini U, Nandeesh BN. Physiology of bone formation, remodeling, and metabolism, radionuclide and hybrid bone imaging. India; 2012.

21. Zheng X, Lee SK, Chun OK. Soy isoflavones and osteoporotic bone loss: a review with an emphasis on modulation of bone remodeling. J Med Food. 2016; 19(1): 1-14.

22. Greendale GA, Espeland M, Slone S, Marcus R, Barrett-Connor E. Bone mass response to discontinuation of long-term hormone replacement therapy: results from the Postmenopausal Estrogen/Progestin Interventions (PEPI) Safety Follow-up Study. Arch Intern Med. 2002; 162: 665. 